\title{
Undervisning - forventninger og fortolkning
}

\section{Helle Mathiasen}

Lektor, ph.d.

Institut for Informations- og Medievidenskab

Århus Universitet

hema@imv.au.dk

http://www.imv.au.dk / http://person.au.dk/da/hema@imv

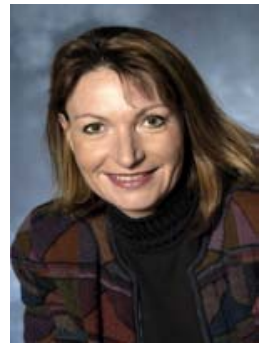

\section{Tina Bering Keding}

Studielektor, ph.d.

Pædagogisk Udviklingscenter,

Institut for Uddannelse, Læring og Filosofi

Aalborg Universitet

tbk@learning.aau.dk

http://www.learning.aau.dk / http://personprofil.aau.dk/Profil/104021

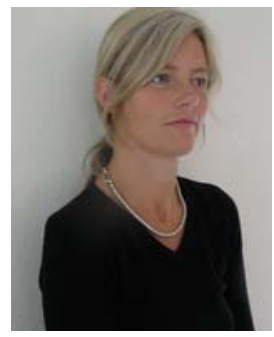

Helle Mathiasen er lektor, ph.d. og leder af forskningscenter for it og løring på Aarhus Universitet.Forskningsmcessigt arbejder Helle Mathiasen ud fra en systemteoretisk optik, blandt andet med genbeskrivelse af den almene didaktiks centrale begreber og koblingen mellem digitale medier, netbaserede kommunikationsfora og andre undervisningsfora som ramme for videnskonstruktion. Undervisningsmcessigt er fokus på overbygningsfag inden for kandidatlinieuddannelsen "Kommunikation, formidling og lering". Hertil kommer foredrag om undervisning, lering, brug af digitale medier og netbaserede kommunikationsfora.

Tina Bering Keiding (f. 1961) er uddannet civilingeniør fra Aalborg Universitet og har en ph.d. grad inden for området teoretisk didaktik fra samme sted. TBK er ansat på Pcedagogisk Udviklingscenter på Aalborg Universitet, og som ekstern lektor på Høgskolen i Agder, Norge. Forskningsmcessigt arbejder TBK ud fra en systemteoretisk optik, blandt andet med genbeskrivelse af den almene didaktiks centrale begreber og problemorienteret projektorganiseret undervisning. Undervisningsmœessigt spœender opgaverne fra intern didaktisk efteruddannelse af universitetsansatte over undervisning og vejledning på uddannelser under Studiencevn for Lœring, samt undervisning af førsteårsstuderende på Arkitektur \& Design i projekt- og gruppearbejde. Hertil kommer en del eksternt rekvireret efteruddannelse.

\section{Indledning}

Uddannelsessystemet er i dag på alle niveauer præget af, at en række nye - ofte it-baserede undervisningsformer bringes ind som supplement til eller erstatning for velkendte undervisningsformer. En række af disse nye undervisningsformer er kendetegnet ved, at der rettes nye og andre forventninger til de studerendes deltagelse, end de kender fra deres hidtidige deltagelse i uddannelsessystemet. 
Artiklen tager udgangspunkt i empiriske iagttagelser, af hvordan studerendes forventninger præger deres tilgang til undervisning. Et vigtigt aspekt ved iagttagelse - både generelt og specifikt hvad angår undervisning - er nemlig, at iagttagelse ledsages af en løbende tilskrivelse af mening eller betydning. Denne meningstilskrivelse sker ved, at det iagttagne sammenholdes og vurderes i forhold til iagttagerens forventning til og viden om, hvordan undervisning plejer eller bør være. Dermed fungerer forventninger som fortolkningsramme for, hvordan der skal deltages og for, hvordan undervisningen vurderes.

I nogle tilfælde er studerendes aktuelle forventninger ikke i samsvar med krav og forventninger til deltagelse som underviserne og uddannelsesinstitutionen stiller, hvilket kan have to udfald. Enten fastholder den studerende sin forventning til, hvad god undervisning er, eller den studerende reviderer gennem læring sine forventninger til undervisning.

Artiklen formulerer i relation hertil tre pointer, nemlig at revision af forventninger kan være nødvendigt for at kunne deltage i de nye undervisningsformer på en måde, som befordrer læring; at et vigtigt afsæt for denne læring er kommunikation om forventninger og endelig at kommunikation om og justering af forventninger i nogle tilfælde ikke sikres gennem "information” men må indtænkes som en del af undervisningen, altså gøres til genstand for didaktisk refleksion. Artiklen kommer afslutningsvis med bud på, hvordan undervisningen kan bidrage til læring som muliggør den tilstræbte deltagelse. På den måde rummer artiklen både refleksioner over og anvisninger for undervisning.

\section{Teoretisk optik}

Det følgende afsnit retter sig mod læsere, der ønsker indsigt i præmisserne for artiklens konklusioner og perspektiver.

De forskningsprojekter, der danner udgangspunkt for artiklen, er alle gennemført inden for en systemteoretisk optik, sådan som den er formuleret af den tyske sociolog Niklas Luhmann. Centralt i denne optik er en skelnen mellem undervisning som et socialt system, baseret på kommunikation, og læring som forandringer i deltagernes bevidsthedssystemer/psykiske systemer.

En anden grundlæggende præmis er, at de to systemtyper beskrives som funktionelt lukkede, men strukturelt koblede. Denne kombination af funktionel lukkethed og strukturel kobling betyder, at de to systemtyper ikke kan gribe kausalt ind i hinanden, men giver samtidig mulighed for, at de kan "forstyrre" eller indvirke på hinanden. Undervisning kan med andre ord stimulere til, men ikke styre eller sikre læring.

Udgangspunktet er dermed, at den enkelte studerende ved at rette opmærksomheden mod undervisningen kan lære sig noget ved deltagelse i undervisning. Undervisningens funktion bliver at etablere en særlig form for kommunikation, der - ved at forstyrre og give "næring til tanker” - skaber en ramme, som bidrager til, at den studerende kan lære sig de krævede kvalifikationer og kompetencer.

For såvel psykiske som sociale systemer gælder, at deres strukturer ses som forventningsstrukturer. At et individ "ved" noget betyder derfor, at det psykiske system gennem læring har udviklet strukturer, der gør, at vedkommende har bestemte forventninger til sig selv og omgivelserne, som fungerer som tolkningsramme og som gør at vedkommende ikke er henvist til at handle tilfældigt.

Læreprocessen, altså den proces der forandrer psykiske systemers forventningsstrukturer, ses her som en hændelse bestående af to elementer. Det første element er knyttet til iagttagelse af "noget" gennem skelnen og betegnen. At skelne betyder her at markere en forskel. Gennem denne forskel kløves verden så at sige i to: Noget betegnes, mens alt andet fremstår uiagttaget. Hvilke forskelle der anvendes, henviser både til det iagttagende psykiske system (den 
studerende og dennes aktuelle viden og forventninger) og til omverdenen (noget i omverdenen kan tiltrække opmærksomheden mere end andet). I læreprocessens andet element føres det iagttagede tilbage til den studerendes psykiske system, hvor resultatet af den nye iagttagelse indføjes i og ændrer de eksisterende forventningsstrukturer (Luhmann 1997,53).

Hvad vi ved, altså resultatet af en læreproces, er således knyttet til den skelnen, vi foretager altså til hvordan vi iagttager. Derfor bliver resultatet af læreprocessen ikke et aftryk, men en re-konstruktion af omverdenen.

Det forhold, at læring ses som forandringer, der henviser til det psykiske system, frem for til undervisningen eller systemets omverden i en bredere betydning, har to væsentlige implikationer. For det første får vi at gøre med et radikalt konstruktivistisk læringsbegreb, som adskiller sig grundlæggende fra de læringsteorier, der beskriver samspillet mellem omgivelser og læring ud fra overførsels- eller transmissionsmetaforer. For det andet sættes fokus på, at hvordan den studerende aktuelt iagttager og forstår undervisningen, får afgørende indflydelse på både den aktuelle læring og på, hvordan undervisningen som social interaktion opfattes og hermed på forventninger til egen deltagelse i undervisningen.

Forventninger kan "fortættes til fordringer" (Luhmann 2000, 13). Ved denne "fortætning” får det forventede en mere grundlæggende funktion i det psykiske system. Brudte forventninger og oplevet skuffelse vil i tråd hermed rumme en tilsvarende større udfordring for systemets stabilitet. Det er her i feltet for uopfyldte fordringer, at følelserne gør deres indtog. Brudte forventninger til undervisningen, som den studerende ikke umiddelbart er indstillet på at ændre, kan derfor i nogle tilfælde iagttages indirekte gennem følelsesmæssige udbrud. Følelser anskues med en Luhmann-inspireret optik ud fra et funktionelt perspektiv og ses som en slags beslutningsstrategi, som træder i funktion, når et psykisk system oplever sig forstyrret på måder, der ikke peger frem mod nye handlinger, forståelser og forandring af forventninger. I sådanne situationer muliggør "opblussen af følelser”, at der besluttes uden skelnen til konsekvenserne (Keiding 2002).

\section{Forventninger til og i undervisning}

I en række empiriske studier har vi beskæftiget os med studerendes deltagelse i og opfattelse af undervisning. Disse forskningsbaserede undersøgelser fortæller alle, at deltagelse i og opfattelse af undervisning ikke handler om den tilbudte og gennemførte undervisning, men om deltagernes forventninger til, erfaringer med og præferencer for undervisning. I nogle tilfælde gøres forventningerne eksplicit til tema i kommunikation om undervisning; i andre tilfælde iagttages forventningerne mere indirekte.

Vi vil her præsentere to eksempler på, hvordan forventninger indvirker på deltagelse i og opfattelse af undervisning. Fælles for eksemplerne er, at de er et resultat af forskningsbaserede, kvalitative undersøgelser. For indblik i metodiske aspekter, hvad angår frembringelse og fortolkning af disse forskningsresultater, henvises til Mathiasen (2002, 2003a, 2003b, 2004 \& 2006), Keiding (2005 A\&B) samt Keiding \& Vardinghus-Nielsen (2004).

Det første eksempel stammer fra en analyse af studerendes tilfredshed med vejledningen på Det teknisk-naturvidenskabelige Basisår på Aalborg Universitet. I undersøgelsen stilles de studerende blandt andet følgende spørgsmål: "Hvad har vejlederen gjort godt og hvordan” og "Hvad har vejlederen gjort dårligt og hvordan”.

De studerendes besvarelser kan på baggrund af rapportens udvalgte citater sammenfattes i to kategorier. Den første udtrykkes gennem formuleringer som "Vi er tilfredse med vejledning, fordi vejlederen hjalp, når vi havde brug for det”, mens den anden kommer til udtryk gennem formuleringer af typen "Vi er tilfredse fordi vejlederen har udfordret os og tvunget os til selv 
at træffe valg”. Et udsagn af sidstnævnte kategori efterfølges af refleksionen: ”Det var godt bagefter” (KUG-Årsrapport 1997-1999).

De to kategorier er ens i den forstand, at de begge udtrykker tilfredshed med vejledningen, men forskellige i hvilken forskel, der betinger eller rammesætter tilfredsheden. I det ene tilfælde er de studerende tilfredse, fordi vejlederen har hjulpet og støttet, mens tilfredsheden i den anden begrundes med, at vejlederen har udfordret de studerende.

Det, at der anvendes to forskellige forskelle ved iagttagelse af vejledningen, ses om udtryk for, at de studerende tematiserer forskellige forventninger til god vejledning. Forventer en studerende, at vejlederen retter arbejdsblade og giver svar på alle spørgsmål - altså hjælper vil en udfordrende vejledning, som sætter fokus på at den studerende selv træffer valg, kunne opfattes som utilfredsstillende. Beder man den selv samme studerende om at vurdere vejledningen ud fra, om den har støttet i opfyldelse af uddannelsens målsætninger, kan svaret sagtens være, at det lige på den måde var en god vejledning.

En og samme vejledning kan således opleves god eller tilfredsstillende ud fra én forventningshorisont, mens den ud fra en anden forventningshorisont vil opfattes som ikke-tilfredsstillende.

Det andet eksempel, hvor empiriske resultater gør det relevant at anslå forventningstemaet, handler om en suppleringsuddannelse på Århus Universitet. Forløbet består af fire fagmoduler og et afsluttende problembaseret deltagerstyret projektforløb. Nogle af fagmodulerne afvikles som forholdsvis traditionelle lærerformidlede oplæg. Andre moduler er udformet som længerevarende seminarer, typisk af to dages varighed, og afvikles i kombination med længerevarende selvstændige fordybelsesperioder. Disse seminarer indeholder lærer-, gæsteog studenteroplæg, konferenceaktiviteter samt gruppe- og plenumbaserede diskussioner. Projektperioden afvikles som selvstændigt arbejde med mulighed for at deltage i projektseminarer og vejledning. Fælles for alle uddannelsens elementer er, at de understøttes af et net-baseret konferencesystem.

På baggrund af de studerendes deltagelse i og evaluering af dette uddannelsesforløb kan de groft deles op i to kategorier, hvor den ene kan karakteriseres som studerende, der kan håndtere "det nye". Et eksempel på, hvordan en studerende fra denne gruppe iagttager undervisningen, lyder: "undervisningen var spændende. Den store frihed i forhold til at vælge, hvilket område man ville arbejde med, var krævende i forhold til selv at strukturere udvælgelse og læsning af litteratur, men samtidig meget givende pga. muligheden for at lade interessen styre.” (Mathiasen 2006)

Andre studerende i denne gruppe begrunder tilfredshed med suppleringsuddannelsens tilrettelæggelse i en praktisk lettelse ved at kunne arbejde i mindre grupper uden for uddannelsens fysiske rammer, ofte fordi der er tale om geografiske afstande mellem de studerende, hvilket giver netmedieret kommunikation en særstilling. Det betyder ikke, at de nødvendigvis ville foretrække undervisning, der er tilrettelagt som den her beskrevne, hvis de var geografisk tættere på uddannelsesinstitutionen.

Den anden kategori kan karakteriseres som studerende, der udtrykker modvilje mod den uvante uddannelsesstruktur, og som er tryghedssøgende i den forstand, at de forventer - eller endda fordrer - at pensum, litteraturlister og lignende fremstår, som de kender det fra deres grunduddannelse. Det er ikke nok, at der ligger seminarplaner med litteraturangivelser, inspirationslitteraturlister, tekster i konferencen og angivne temaer for de enkelte undervisningsaktiviteter. Disse studerende ønsker yderligere kompleksitetsreduktion, eksempelvis i form af en liste over litteratur, der skal læses og som bliver opgivet til eksamen. En studerende fra denne gruppe skriver i semesterevalueringen "Det har været et helt nyt felt at skulle danne sig et overblik over og derfor synes jeg det har været frustrerende ikke at have 
noget at holde mig til.[...] jeg ville foretrække at have en læseplan, der er delt op [...] derudover ville jeg også have foretrukket at kurset havde forløbet regelmæssigt i stedet for opdelt i seminarer - det bliver så mærkeligt afbrudt” (Mathiasen 2006).

For nogle studerende er studieforløbet således tydeligt komplekst og stiller store og nye krav til deres evne til at selektere og prioritere i forhold til undervisningens indhold og form. Dette kan betyde, at undervisningens forventninger om, at studerende udviser selvstændighed, selvdisciplin og ansvarlighed har vanskelige betingelser i forhold til denne kategori af studerende. De ønsker hyppigere og mere regelmæssige forelæsninger/holdundervisning og gerne et skema, der gælder eksempelvis et semester. De vil gerne have pensum detaljeret beskrevet. Endvidere ønsker de at få "lektier for" til hver undervisningsgang og aflevere opgaver, som "bliver rettet". De efterspørger med andre ord genkendelige rammer, og giver udtryk for at under disse betingelser, vil de kunne læse pensum og "levere varen” til eksamen.

Samtidig viser forskning, at netop den kontinuerlige aktive deltagelse, som i netmedieret undervisning i vid udstrækning kun kan sikres gennem den studerendes ansvarlighed og selvdisciplin, er altafgørende for, at vedkommende bliver en del af holdet. Tolerancen blandt medstuderende er ganske høj i forhold til manglende faglig kvalitet i kommunikationsbidragene, hvorimod manglende aktiv deltagelse fører til både faglig og social eksklusion (Mathiasen 2005, Keiding \& Vardinghus-Nielsen 2004).

Dette peger i retning af, at vanskeligheder ved deltagelse i disse nye undervisningsformer ikke blot vil have negative læringsmæssige og sociale konsekvenser i forhold til det specifikke kursusforløb, men kan medføre en mere generel ekskludering fra uddannelsesforløbet.

\section{Diskussion og tolkning af resultater}

Fælles for de to eksempler er, at informationerne kan tolkes på den måde, at de studerende i udgangspunktet har nogle erfaringsbaserede forventninger til henholdsvis, hvad god vejledning er og hvad det vil sige at deltage i undervisning, og at de anvender disse forventninger til at tolke og vurdere konkrete forløb.

Hvad angår suppleringsuddannelsen, gælder for begge kategorier af studerende, at de overraskes af den nye undervisningsform. De adskiller sig ved, at den førstnævnte kategori i høj grad er parate til - og værdsætter - at der rettes nye forventninger til dem, mens den anden kategori prøver at overføre forventninger fra skoleundervisning til universitetsundervisning. Man kan sige, at hvor den ene gruppe af studerende reviderer deres forventninger, altså lærer om undervisning (OK, sådan kan undervisning også foregå), så tilstræber den anden gruppe at fastholde deres forventninger til god undervisning (velkendte former, trygge rammer osv.) og vurderer derfor det konkrete forløb som vanskeligt eller måske endda dårligt.

Med inspiration fra den anlagte systemteoretiske ramme kan man sige, at forventningerne hos den første kategori bærer præg af kognitive forventningsstrukturer, som revideres, da noget andet viser sig "at være tilfældet”. Den anden kategori tilstræber - sikkert af mange forskellige grunde - at fastholde kurset som "en undtagelse" i forhold til, hvordan undervisning "bør” være. Her synes således at være tale om, hvad Luhmann betegner som normative forventningsstrukturer i forhold undervisningens tilrettelæggelse og gennemførelse. Kendetegnende for normative forventninger er, at en ønsket tilstand tilstræbes genetableret ved at rette krav om forandringer mod omgivelserne, frem for at revidere forventningerne til en selv.

Hvad angår eksemplet med vurdering af vejledning giver det empiriske materiale ikke grundlag for at sige noget om, hvorvidt de studerende, der værdsætter den udfordrende vejledning, også har gennemgået en læreproces i forhold til deltagelse i vejledning eller om vejledningen fra starten var i samsvar med deres forventninger. Dog antyder formuleringen 
"det var godt - bagefter", at den markerede tilfredshed kan have været ledsaget af en oplevelse af, at det ikke føltes helt så godt i begyndelsen, men at forventningerne til god vejledning blev revideret undervejs.

Der er med andre ord ret tydeligt, at forventning til undervisning, herunder også vejledning, får afgørende betydning for såvel deltagelse i som vurdering af et givet forløb. Ikke blot i forhold til om det opleves som god eller dårlig undervisning, men også i forhold til hvad den studerende forventer af de forskellige deltagere i undervisningen, herunder hvad der forventes af underviseren.

Det betyder, at tilfredshed med undervisning og vejledning i højere grad handler om indfrielse eller skuffelse af forventninger til vejledning, end til hvad underviseren/vejlederen gør og ikke gør.

Vi har valgt en grov skelnen mellem studerende, der tilsyneladende håndterer en ny og overraskende undervisningsrelateret kompleksitet gennem læring og studerende, for hvem dette ikke sker. For nogle studerende er den læring, og de hertil relaterede kommunikative handlinger, der er nødvendige for at kunne deltage i de nye undervisningsformer noget, der nærmest bare sker, og måske endda - efter en forbigående forbløffelse - opleves som særdeles motiverende ("giver et kick").

Anderledes stiller det sig med den kategori, som stiller sig tøvende eller afvisende overfor de nye tiltag. Her kan det iagttages, at de ikke deltager som intenderet og at de ikke bryder sig om undervisningsformen, men ikke om det er fordi, de ikke vil lære at undervisning kan foregå på en anden måde, eller om de måske ikke kan lære det under de aktuelle betingelser.

I lyset af 1990'ernes fokus på ansvar for egen læring, og den hertil hørende formulering om at mangelfuld læring skyldes mangelfulde beslutninger om at lære, ligger forklaringen lige for: De vil ikke tage ansvar for egen læring (Baird \& Northfield 1995:142). Eller med briller fra det nye årtusinde hverken besidder eller formår de at udvikle de typer af kompetencer, som karakteriseres med begreber som fleksibilitet, ansvarlighed, selvstændighed, samarbejdsevne og kompleksitetshåndtering. Fælles for disse beskrivelser er, at manglende læring personificeres og dermed tilskrives mangler eller "fejl” hos de studerende.

Men hvad nu hvis det ikke bare er et spørgsmål om at "tage sig selv i nakken” og lære de nye studiekompetencer. Hvad nu hvis disse studerende faktisk ikke kan begribe, hvad det er, de skal tage ansvar for og hvordan det skal gøres?

Med forståelser fra den teoretiske ramme vil et nyt fænomen - hvad enten det er projektarbejde med tilknyttet vejleder, it-medieret undervisning eller noget helt tredje - blive i agttaget og forstået med afsæt i, hvad de studerende ved og kender i forvejen, og hvordan fænomenet gør sig iagttageligt for dem. De studerende vil med andre ord lære om og skabe mening i det nye med reference til noget kendt, og hvad de kan observere. Denne læring kan i nogle tilfælde ske sådan "vupti": "hold da op - det er helt anderledes". I andre tilfælde kan den ledsages af en oplevelse af, at det er "mindre fedt", og at de egentlig helst vil være dette nye foruden. Det betyder dog ikke, at de ikke kan og vil være villige til lære det, hvis de forstår, hvorfor undervisningen er tilrettelagt på denne umiddelbart uvante og forstyrrende måde.

Går vi ud fra, at den konstaterede ikke-læring beror på, at den studerede med sin aktuelle viden og gennem sine iagttagelse af undervisning, faktisk ikke kan se meningen med disse nye undervisningsformer eller identificere, hvad det egentlig er, der forventes og dermed hvad, der skal læres for at kunne deltage, bliver det klart, at den studerende reelt står med et "dobbelt" læringsproblem. Der skal både læres et nyt indhold og læres om deltagelse i undervisning. Men med denne tilgang bliver manglende læring - både i forhold til nye 
undervisningsformer og generelt - et problem for undervisningen og dennes deltagere, frem for et problem med og hos den enkelte studerende. Og dermed et problem som kan og skal løses i undervisningen. For ganske som undervisning kan tilrettelægges så den støtter læring af nyt indhold, kan den også tilrettelægges på måder, der støtter læring af nye former for deltagelse i undervisning.

\section{Konklusion og didaktiske perspektiver}

Ofte er gensidige forventninger til deltagelse ikke et tema i undervisningen. I bedste fald søges det relevante og nødvendige forventningsgrundlag sikret gennem information om, hvordan der skal deltages og hvorfor der skal deltages på netop denne måde, dvs. hvorfor undervisningen retter netop disse forventninger mod den studerende. Men med Luhmann må man fastholde, at disse informationer ikke nødvendigvis forstås af de studerede på samme måde, som underviseren eller vejlederen forventer.

Forventning om selvstændig deltagelse kan fra underviserside måske betyde, at den studerende selv skal finde relevant litteratur, mens den studerende kan forstå det som en krav om, at man danner sine egne meninger om undervisningens temaer. Men selv hvis informationerne forstås som intenderet, er det ikke givet, at de fører til, at den studerende deltager som forventet. Hvordan sådanne informationer anvendes som en del af rammesætningen for deltagelse i undervisning henviser nemlig både til, hvordan disse informationer er forstået, og hvordan de "sammen-konstrueres" med eksisterende viden. Måske vælger studerende - trods en fornemmelse af, at der egentlig stilles nye krav - at deltage som vanligt. Simpelthen fordi det ikke er indlysende, hvilke nye handlinger, der skal til for at leve op til de nye forventninger. Ved man ikke, hvordan man skal tage de udfordringer op, som stilles fra underviser eller vejleder, kan fastholdelse af velkendte fremgangsmåder blive et oplagt alternativ, frem for at forsøge at lære noget uidentificerbart nyt.

Hvis sandsynligheden skal øges for, at alle studerende får udbytte af disse nye undervisningsformer, fordrer det for os at se, at der allerede ved planlægning af undervisning/vejledning tages højde for problemstillingen om forventninger til og muligheder for at lære den forventede form for deltagelse. Derfor vil vi afslutningsvis formulere nogle enkle didaktiske konsekvenser ud fra de præsenterede empiriske observationer samt det anlagte teoretiske grundlag.

Helt grundlæggende peger resultaterne på, at ikke blot sagen/indholdet, men også arbejdsformen må gøres til genstand for undervisning, hvis også de studerende, som ikke bare sådan "vupti” lærer sig det nye, skal kunne deltage. Her tænker vi ikke blot på undervisning som formidling af information, men undervisning som kommunikation med fokus på løbende forståelseskontrol, afprøvning og mulighed for korrektion af fejl og misforståelser gennem feedback. Der skal med andre ord tænkes i undervisning med et tydeligt islæt af formativ og summativ feedback, ikke blot i forhold til undervisningens indhold, men nok så afgørende i forhold til hvordan den studerende deltager, og hvordan denne deltagelse "matcher" undervisningens forventninger og uddannelses fordringer.

Dette sætter fokus på refleksiv kommunikation, forstået som kommunikation om undervisningens kommunikation og handlinger. Den refleksive kommunikation bør rumme to dimensioner. For det første må den tilstræbe at skabe indsigt i, hvordan deltagerne - dvs. både undervisere og studerende - fortolker undervisningen. Med andre ord, hvilke forventninger retter de mod undervisning og deres egen deltagelse. En sådan afklaring anses for at kunne bidrage til synliggørelse af sammenfald og divergenser mellem de studerendes forventninger og lærerens forventninger. Er en projektrapport fx en variation af dansk stil eller snarere en variation af fysikrapporten eller måske noget helt tredje? Denne afklaring kan videre danne grundlag for diskussion af og muligheder for justering af disse forventninger. 
For det andet må den refleksive kommunikation sætte fokus på forståelseskontrol. Forståelseskontrol handler om, at undervisningen løbende kommunikerer om, hvordan deltagerne forstår undervisningen. Dette forekommer som en integreret del af undervisningens faglige temaer i de fleste undervisningsformer og kommer til udtryk i seminarer, fremlæggelser, besvarelse af opgaver osv. Langt sjældnere er det, at undervisningen også kommunikerer om, hvordan de studerende forstår de forventninger, undervisningen retter mod dem. Hvad forstår de for eksempel ved at skulle "arbejde selvstændigt med et tema”, og hvilke handlinger, mener de, vil være relevante for at indfri denne forventning (Når du gør sådan, opfatter jeg det som udtryk for at du tolker selvstændighed på en anden måde end jeg).

Det er klart, at et sådant fokus på deltagelse i undervisning kan opfattes som et sidespor i forhold til undervisningens mål og indhold, forstået som at den tid, der bruges til kommunikation om deltagelse, "går fra fagligheden”. Et andet blik på indførelse af endnu et tema i undervisningen er, at iagttagelse af og læring om undervisningens form faktisk kan være en nødvendig betingelse for, at deltagerne overhovedet kan iagttage undervisningens mål og indhold som intenderet. Og dermed en nødvendig forudsætning at undervisningen opfylder sin funktion om at bidrage til en intenderet faglig læring. Ydermere er det man i dele af det danske uddannelsessystem kan betegne som relativt nye undervisningsformer, som eksempelvis problemorienteret deltagerstyret projektarbejde og it-medierede undervisningsmiljøer, netop introduceret med henblik på at give rammer for læring af kompetencer, der rækker udover det snævert faglige, hvilket er endnu et argument for at sætte fokus på, hvordan der deltages i undervisning.

Med disse anbefalinger turde det være tydeligt, at vores afsæt i et endog ganske radikalt konstruktivistisk læringsbegreb ikke leder frem til en antagelse om, at den studerende står alene med ansvaret for at lære sig det, der nu skal læres om undervisningens indhold og form. Undervisningen skal - som kontekst for læring - bidrage til at støtte den tilstræbte læring, og det er blandt andet underviserens opgave gennem sit didaktiske planlægningsarbejde at bidrage til at etablere muligheder her for.

\section{Referencer}

Baird, John R., \& Northfield Jeff R. (eds). (1995). Erfaringer fra PEEL-projektet: et australsk laringsforsøg. Århus: Klim

Keiding, Tina B. (2002). Hvor gør man af følelserne - om det kognitive og det affektive hos Niklas Luhmann. Luhmann anvendt. Eds. Jens Rasmussen. København: Unge pædagoger

Keiding, Tina B. \& Vardinghus-Nielsen, Henrik. Inklusion/eksklusion: Et perspektiv på en flex-klasse på et studenterkursus. Det virtuelle gymnasium - 2. del af følgeforskningsrapport om et udviklingsprojekt. Udviklingsprogrammet for fremtidens uddannelser. Helle Mathiasen (eds.) København: Uddannelsesstyrelsen. http://us.uvm.dk/gymnasie/almen/it/DVG-rapport2.pdf

Keiding, Tina. B. (2005a). Hvorfra min verden går. Et Luhmann-inspireret bidrag til didaktikken. Aalborg: Institut for Læring, Aalborg Universitet.

Keiding, Tina B. (2005b). Simpel, kompleks og hyperkompleks forståelse - tre måder at begribe omverdenen på. Bidrag til Nordisk Systemteoretisk Netværks konference "Systemteoriens anvendelse og anvendbarhet". Institut for Sosiologi. Universitet i Tromsø. (Manuskript)

KUG-årsrapport 1997-1999. Den interne kvalitetsudviklingsgruppe (KUG). Den teknisk naturvidenskabelige basisuddannelse, Aalborg Universitet.

Luhmann, Niklas. (1997). Autopoiesis - problemer omkring operativ lukning. Iagttagelse og paradoks. Essays om autopoietiske systemer. Niklas Luhmann (eds). København: Gyldendalske Boghandel, Nordisk Forlag

Luhmann, Niklas. (2000). Sociale systemer. København: Hans Reitzels forlag 
Mathiasen, Helle. (2002). Personlige bcrbare computere i undervisningen. Ph.d.-afhandling. København: DPU's forlag

Mathiasen, Helle. (2003a) Udviklingsprojektet ”Det virtuelle gymnasium”. Følgeforskningsrapport 1, skoleåret 2002/2003, Bind I. København: Undervisningsministeriets forlag. www.uvm.dk

Mathiasen, Helle (red.). (2003b). Udviklingsprojektet ”Det virtuelle gymnasium”. Følgeforskningsrapport 1, skoleåret 2002/2003, Bind II. Bilagsmateriale. København: Undervisningsministeriets forlag. www.uvm.dk

Mathiasen, Helle (red.). (2004).Udviklingsprojektet ”Det virtuelle gymnasium”. Følgeforskningsrapport 2. København Undervisningsministeriets forlag, http://us.uvm.dk/gymnasie/almen/it/DVG-rapport2.pdf

Mathiasen, Helle. (2005). Projektorganiseret og netstøttet undervisning - En invitation til udvikling af lærer- og elevroller. Medier og it - lœringspotentialer. Mie Buhl, Holm Sørensen, Birgitte; Meyer, Bente (eds.). København: Danmarks Pædagogiske Universitetsforlag

Mathiasen, H. (2006). Undervisning og kompetenceudvikling - pædagogiske intentioner og studerendes forventninger og forudsætninger. Lœring og it- kompetenceudvikling på de videregående uddannelser. Mathiasen, H. (red.) Århus: Aarhus Universitetsforlag 